\title{
Preparation and characterization of spermine-exchanged montmorillonite and
} interaction with the herbicide fluometuron

Beatriz Gámiz $^{\mathrm{a}}$, Rafael Celis ${ }^{\mathrm{a}, *}$, M. Carmen Hermosín ${ }^{\mathrm{a}}$, Juan Cornejo ${ }^{\mathrm{a}}$, Cliff T. Johnston ${ }^{\mathrm{b}}$

${ }^{\text {a } I n s t i t u t o ~ d e ~ R e c u r s o s ~ N a t u r a l e s ~ y ~ A g r o b i o l o g i ́ a ~ d e ~ S e v i l l a ~(I R N A S), ~ C S I C, ~ A v e n i d a ~ R e i n a ~}$ Mercedes 10, P.O. Box 1052, 41080 Sevilla, Spain

${ }^{\mathrm{b}}$ Crop, Soil and Environmental Sciences, Purdue University, 915 West State Street, West Lafayette, IN 47907-2054, USA

\section{Corresponding author:}

Dr. Rafael Celis

Instituto de Recursos Naturales y Agrobiología de Sevilla (IRNAS), CSIC

Avenida Reina Mercedes 10, P.O. Box 1052

41080 Sevilla

SPAIN

Phone: +34954624711

Fax: +34954624002

E-mail: rcelis@irnase.csic.es 


\section{Abstract}

2 We studied the interaction between the naturally occurring polycation spermine (SPERM) and

3 Na-exchanged SWy-2 Wyoming montmorillonite (Na-SWy-2 Mt) and between spermine-

4 exchanged montmorillonite (Mt-SPERM) and the herbicide fluometuron. Mt-SPERM with

5 spermine contents ranging between 0 and 1.2 times the cation exchange capacity (CEC) of

6 Na-SWy-2 were studied by XRD, FTIR and TGA analysis. Spermine was intercalated

7 stoichiometrically into Na-SWy-2 up to the CEC of the clay mineral, resulting in basal spacing of $1.3 \mathrm{~nm}$. TGA analysis indicated that intercalation of spermine into Na-SWy-2 increased the thermal stability of the organic cations and affected the dehydroxylation temperature of the clay mineral. FTIR measurements of Mt-SPERM samples showed the involvement of $\mathrm{N}-\mathrm{H}$ and $\mathrm{C}-\mathrm{H}$ groups of spermine in the interaction with the clay mineral. The intensity of the spermine $\mathrm{N}-\mathrm{H}$ and $\mathrm{C}-\mathrm{H}$ deformation vibrations increased linearly with the amount of spermine incorporated into Na-SWy-2 up to an amount close to the CEC of the montmorillonite. Structural modeling suggested that the arrangement of spermine cations formed a horizontal monolayer within the interlayer space of SWy-2 with strong interaction atoms. Mt-SPERM showed pronounced affinity for the herbicide fluometuron. montmorillonite. 


\section{Introduction}

Clay minerals are an important class of ubiquitous naturally-occurring nanoparticles. Because of their small size, expansive properties, anisotropic shape and reactive surfaces, the importance of clay minerals are recognized in a wide range of disciplines, including those related to their use as adsorbents of organic compounds (Bergaya and Lagaly, 2006; Cornejo et al., 2008; Johnston, 2010). Due to the hydrophilic, negative character of their surfaces, clay minerals, particularly expandable 2:1-type phyllosilicates (i.e., smectites), are good adsorbents for organic cations and polar organic compounds of high water solubility. However, the adsorption of sparingly and poorly soluble organic compounds, including many classes of pesticides, is usually limited (Boyd et al., 2011; Gonen and Rytwo, 2006; Jaynes and Vance, 1996, Mortland, 1970). One mechanism widely used to enhance the affinity of clay minerals for these pesticides consists of replacing the original inorganic exchangeable cations by organic cations by ion exchange. This simple modification changes the nature of the clay mineral surface from hydrophilic to hydrophobic, yielding organo-clay minerals with enhanced affinity for pesticide molecules (Boyd et al., 1988; Cornejo et al., 2008; Groisman et al., 2004; Hermosín and Cornejo, 1992; Mortland et al., 1986; Nir et al., 2006).

The organic cations most commonly used for clay mineral modification are quaternary ammonium ions with alkyl chains and sometimes aromatic groups. Organic cations containing diverse polar functionalities can provide organo-clay minerals with enhanced affinity for particular pesticides (Cruz-Guzmán et al., 2004, 2005). The use of naturally-occurring organic cations for clay mineral modification was pointed out as an important strategy to reduce the possible negative environmental impact of adsorbents introduced into the environment for pollutant immobilization, controlled release of pesticides, and similar environmental applications (Celis et al., 2007; Cruz-Guzmán et al., 2004, 2005; Gámiz et al., 2010). Quaternary alkylammonium ions can exhibit some antimicrobial properties which could limit 
their effectiveness by being toxic to natural xenobiotic degraders since this would hinder natural attenuation of the pollutant in the environment (Nye et al., 1994; Sarkar et al., 2010). The use of organoclays prepared with naturally-occurring organic cations is then of advantage. Fluometuron [N,N-dimethyl-N'-[3-(trifluoromethyl)phenyl] urea] is a pre- and early postemergence phenylurea herbicide widely used to control grass and broad-leaved weeds in cotton and olive crops. Several studies were conducted to understand the behavior of this herbicide in soils, including studies on the effects of tillage and cover crops (Baskaran and Kennedy, 1999; Gaston et al., 2003; Locke et al., 2007; Zablotowicz et al., 2000), degradation studies (Halladja et al., 2007; Mueller et al., 1992; Weaver et al., 2004), as well as the development of different strategies to reduce herbicide losses and mitigate pollution, such as the use of organic amendments (Wagner et al., 1997), controlled release formulations (Zhao and Wilkins, 2003), and constructed wetlands (Locke et al., 2011). High mobility and leaching of fluometuron were reported for soils with low organic matter contents (Mueller et al., 1992) and, according to Baskaran and Kennedy (1999), this herbicide could diffuse through permeable and sandy soils causing groundwater contamination.

In a previous paper, we found that intercalation of the naturally-occurring polycation spermine in SWy-2 Wyoming montmorillonite yielded complexes with high affinities for the herbicide diuron (Celis et al., 2007). A subsequent study confirmed that the high affinity of spermine-exchanged Wyoming montmorillonite for diuron was also found for other phenylurea herbicides such as fluometuron (Gámiz et al., 2010). The objective of the present study was to get further insight into the molecular mechanisms of interaction between spermine (SPERM) and Wyoming montmorillonite (SWy-2 Mt) and between spermineexchanged montmorillonite (Mt-SPERM) and the herbicide fluometuron. 


\section{Materials and methods}

\subsection{Materials}

The Wyoming montmorillonite SWy-2 was supplied by the Source Clays Repository of the Clay Minerals Society (Purdue University). Relevant physicochemical properties of SWy-2 are given in Table 1. Prior to use, SWy-2 was exchanged with $\mathrm{Na}^{+}$by dispersing $40 \mathrm{~g}$ of SWy2 in $1 \mathrm{~L}$ of $0.5 \mathrm{M} \mathrm{NaCl}$ for $24 \mathrm{~h}$. The montmorillonite was washed to remove excess salts by repeated centrifugation with Millipore ${ }^{\circledR}$ water before the $<2 \mu \mathrm{m}$ size fraction $(\mathrm{Na}-\mathrm{SWy}-2)$ was collected by centrifugation, freeze-dried, and stored in a closed container. Spermine tetrahydrochloride (purity $>98 \%$ ) and fluometuron (purity $=99.5 \%$ ) (Fig. 1) were used as supplied by Sigma-Aldrich. Spermine is a naturally-occurring polyamine with four $\mathrm{p} K_{\mathrm{a}}$ values which lie in the interval 8-11 (Frassineti et al., 1995). Thus, the fully protonated form of spermine was predominant at acidic, neutral, and slightly alkaline conditions. Fluometuron is a neutral herbicide with a molar mass 232.2 and water solubility $105 \mathrm{mg} \mathrm{L}^{-1}$ at $20{ }^{\circ} \mathrm{C}$ (Worthing and Hance, 1991).

\subsection{Preparation of self-supporting montmorillonite-spermine films}

A series of seven $20 \mathrm{~mL}$-aqueous solutions of spermine tetrahydrochloride containing an amount of spermine corresponding to $0,0.15,0.30,0.45,0.60,0.90$, and 1.2 times the CEC of Na-SWy-2 (Table 1) were mixed with $25 \mathrm{mg}$ of the montmorillonite in Corex ${ }^{\circledR}$ centrifuge tubes which were then shaken for $24 \mathrm{~h}$ at room temperature. After shaking, the dispersions were stirred, and the volume was divided into two fractions of $10 \mathrm{~mL}$ containing $12.5 \mathrm{mg}$ of solid. The two fractions were filtered separately using membrane filters $(47 \mathrm{~mm}, 0.45 \mu \mathrm{m}$ pore size, Millipore Co. Bedford, MA), and the solids were allowed to dry at room temperature. The air-dried montmorillonite-spermine films were peeled off the membrane sheet as selfsupporting films (SSFs), and used for XRD, FTIR and TGA analysis. 


\subsection{Preparation of self-supporting montmorillonite-spermine-fluometuron films}

Montmorillonite-spermine-fluometuron SSFs were prepared following a procedure similar to that described in the previous section. A series of $20 \mathrm{~mL}$-aqueous solutions containing an amount of spermine corresponding to 0.6 or 1.2 times the $\mathrm{CEC}$ of $\mathrm{Na}-\mathrm{SWy}-2$ were mixed with $25 \mathrm{mg}$ of the montmorillonite in $30 \mathrm{~mL}$ Corex $^{\circledR}$ centrifuge tubes. After $24 \mathrm{~h}$ shaking, the dispersions were centrifuged, the supernatants were removed, and $20 \mathrm{~mL}$ of aqueous solutions of fluometuron with initial herbicide concentrations ranging between 0.1 and $5 \mathrm{mg} \mathrm{L}^{-1}$ were added to the centrifuge tubes, which were then re-equilibrated by shaking for $24 \mathrm{~h}$. After equilibration, the tubes were centrifuged at $6000 \mathrm{rpm}$ for $30 \mathrm{~min}$ before $2 \mathrm{~mL}$ of the supernatant solution were removed. The fluometuron concentration was determined by HPLC. The dispersion remaining in the centrifuge tube was stirred, divided into two fractions of $9 \mathrm{~mL}$ and $12.5 \mathrm{mg}$ of solid, filtered using membrane filters, and allowed to dry at room temperature and analyzed by XRD, FTIR, and TGA. The amount of fluometuron adsorbed $\left(C_{\mathrm{s}}\right)$ was calculated from the difference between the initial $\left(C_{\mathrm{ini}}\right)$ and equilibrium $\left(C_{\mathrm{e}}\right)$ solution concentrations, measured by HPLC using a Waters 600E chromatograph coupled to a Water 996 diode-array detector. The following analytical conditions were used: Novapack C18 column $(150 \mathrm{~mm}$ length $\times 3.9 \mathrm{~mm}$ i.d. $), 60: 40$ water:acetonitrile eluent mixture at a flow rate of $1 \mathrm{~mL} \mathrm{~min}^{-1}, 25 \mu \mathrm{L}$ injection volume, and UV detection at $243 \mathrm{~nm}$.

\subsection{Characterization of the self-supporting films}

\subsection{1. $X$-ray diffraction}

X-ray diffraction (XRD) patterns were recorded with a PANalytical B.V. diffractometer, Model X'Pert PRO (Almelo, Netherlands) with Co radiation. The $\mathrm{d}_{001}$-values were determined for both air-dried SSF and after saturation in water vapor for $24 \mathrm{~h}$. The data were 
collected from $2^{\circ}$ to $80^{\circ} 2 \theta$, counting for $1 \mathrm{~s}$ every $0.02^{\circ} 2 \theta$ step. A $1^{\circ}$ exit Soller slit was used between 2 to $12^{\circ} 2 \theta$. Data analysis was done using X'Pert HighScore Plus software Version 2.2 (PANalytical B.V.).

\subsubsection{Fourier-transform infrared spectroscopy}

Fourier-transform infrared (FTIR) spectra were recorded on a Perkin-Elmer GX2000 spectrometer equipped with deuterated triglycine (DTGS) and Mercury-cadmium-telluride (MCT) detectors, using the spectral range of $4000-580 \mathrm{~cm}^{-1}$. The spectrum of pure spermine (tetrahydrochloride) was recorded by diffuse reflectance spectroscopy. A mixture of $1 \%$ spermine in $\mathrm{KBr}$ was prepared with oven-dried $\left(105^{\circ} \mathrm{C}\right) \mathrm{KBr}$ powder and transferred to a sample cup placed in the diffuse reflectance accessory. The Grams/32 (Galactic software) program was used to analyze and plot spectra.

\subsubsection{Thermogravimetric analysis}

Thermogravimetric analyses (TGA) were conducted in a Mettler Toledo ModelTGA/SDTA851e instrument. The SSFs were ground in an agate mortar and placed in $40 \mu \mathrm{L}$ ceramic crucibles. Thermogravimetric measurements were recorded from $25{ }^{\circ} \mathrm{C}$ to $1000{ }^{\circ} \mathrm{C}$ with a heating rate of $20{ }^{\circ} \mathrm{C} \min ^{-1}$ under a flow of $\mathrm{N}_{2}$. All thermogravimetric curves were normalized to an initial amount of $10 \mathrm{mg}$ of sample.

\subsection{In situ attenuated total reflectance (ATR)-FTIR measurements}

A 2 mL-horizontal trough ATR cell (Pike Technologies, Madison, WI) was used. The internal reflection element (IRE) was the ZnSe crystal with dimensions of $73 \mathrm{~mm} \times 7 \mathrm{~mm}$ and an angle of incidence of $45^{\circ}$. The spectrum of spermine in aqueous solution at a concentration of $30 \mathrm{mM}$ was recorded by adding $2 \mathrm{~mL}$ of spermine tetrahydrochloride solution into the 
ATR-FTIR cell. Then, with the purpose of studying the adsorption of spermine on Na-SWy-2, $5 \mathrm{mg}$ of the montmorillonite were dispersed in $5 \mathrm{~mL}$ of ultra pure water for $30 \mathrm{~min}$ in a water bath sonicator. One $\mathrm{mL}$ of this dispersion containing $1 \mathrm{mg}$ of $\mathrm{Na}-\mathrm{SWy}-2$ was placed in the ATR cell and air-dried overnight, then washed 3 times with $1 \mathrm{~mL}$ of water. The intensity of the $v(\mathrm{Si}-\mathrm{O})$ band was monitored until the solid was water-saturated. Subsequently, $1 \mathrm{~mL}-$ aliquots of the aqueous spermine solution containing an amount of spermine corresponding to 0.15 times the CEC of Na-SWy-2 were added in steps to the cell. After each addition the ATR-FTIR spectrum was recorded and the supernatant was removed from the cell and replaced by $1 \mathrm{~mL}$ of fresh spermine solution. The procedure was repeated until reaching a stable signal of spermine. Then, the procedure was repeated by sequentially increasing the concentration of the spermine solution for a total of 25 additions.

Once saturation of Na-SWy-2 with spermine was completed, the experiment was continued in order to study the interactions between the in situ-formed spermine-montmorillonite deposit and the herbicide fluometuron. For this purpose, the final deposit of montmorillonitespermine resulting from the previous experiment was allowed to dry overnight. Then a series of aqueous solutions of fluometuron with different herbicide concentrations $(0.8,1,2$ and 5 mg $\mathrm{L}^{-1}$ ) were sequentially added for a total of 39 additions. The resolution for FTIR spectra was $2.0 \mathrm{~cm}^{-1}$, and a total of 64 scans were collected for each spectrum.

\subsection{Structure modeling}

The molecular structure of spermine-exchanged montmorillonite was generated using molecular dynamics employing the CLAYFF force field implemented in the Material Studio Version 4.2 software (Accelrys, Inc., San Diego, CA). This software was also used to determine the interatomic distances in spermine and fluometuron (Fig. 1). 


\section{Results and discussion}

\subsection{Montmorillonite-spermine}

\subsection{1. $X$-ray diffraction}

The air-dried SSF of Na-SWy-2 without spermine had a basal spacing of $1.27 \mathrm{~nm}$ (Fig. $2 \mathrm{~A}$ ), which was consistent with the presence of $\mathrm{Na}^{+}$retaining one layer of hydration water in the interlayer space (Chipera and Bish, 2001; Johnston, 2010; Nam et al., 2009). The $\mathrm{d}_{001^{-}}$ value of $1.29 \mathrm{~nm}$ recorded for the samples reacted with the highest amounts of spermine $(0.9$ and $1.2 \times$ CEC) was lower than previously reported values for alkylammonium-exchanged montmorillonites (Jordan, 1949; Lagaly, 1981; Serratosa et al., 1984), but similar to the value reported by Celis et al. (2007) for an air-dried spermine-saturated SWy-2 raw sample. These samples with higher amounts of spermine showed well defined, intense basal reflections, thus indicating well-ordered systems (Fig. 2). Samples with low spermine contents showed $\mathrm{d}_{001^{-}}$ values $(1.42-1.47 \mathrm{~nm})$ larger than that of the original Na-SWy-2 sample and of the samples with the highest amounts of spermine due to the presence of both hydrated $\mathrm{Na}^{+}$and spermine cations in the interlayer space of the air-dried samples. Quantitative displacement of the $\mathrm{Na}^{+}$ ions by spermine cations at higher spermine additions yielded a dense arrangement of the organic cations in the interlayer space.

The basal spacings of water-saturated SSF (Fig. 2B) around $1.45 \mathrm{~nm}$ recorded for samples with low spermine content and without spermine indicated the presence of two layers of water molecules associated with $\mathrm{Na}^{+}$ions in the interlayer space. The fact that the basal spacing of samples with higher amounts of spermine remained unchanged at $1.29 \mathrm{~nm}$ after saturation with water (Fig. 2B) revealed that the spermine cations held the montmorillonite layers together and prevented further expansion of the lattice when exposed to high relative humidity. This result could be indicative of the high attraction between the four ammonium groups of spermine and the negative layer charges. A similar behavior was observed in related 
organoclay complexes prepared with nitroaromatic compounds (Li et al., 2004; Sheng et al., 2002).

\subsubsection{Thermal analysis}

The TGA curve of Na-SWy-2 without spermine was characterized by two mass loss features (Fig. 3), one around $100^{\circ} \mathrm{C}$ with a shoulder at $135^{\circ} \mathrm{C}$ for water loss, and the other one near $700^{\circ} \mathrm{C}$ for the dehydroxylation of the clay mineral (Xi et al., 2005). In contrast, the decomposition of the spermine-exchanged montmorillonites occurred in three steps (Fig. 3), in agreement with previous studies (Celis et al., 2007; Xi et al., 2005; Yariv, 2004). The first mass-loss step, corresponding to water loss, occurred at the same temperature as for unmodified montmorillonite, near $100^{\circ} \mathrm{C}$. With increasing spermine content, this mass loss became less pronounced and the shoulder at $135^{\circ} \mathrm{C}$ disappeared, thus indicating that the interlayer spermine was much less hydrated than the interlayer $\mathrm{Na}^{+}$ions. The second mass loss between 200 and $550{ }^{\circ} \mathrm{C}$ can be assigned to the decomposition of the organic cations. The second mass loss step of spermine-montmorillonite was located at a considerably higher temperature $\left(\sim 475^{\circ} \mathrm{C}\right)$ compared to pure spermine tetrahydrochloride $\left(\sim 375^{\circ} \mathrm{C}\right)$, showing that spermine was protected by the montmorillonite layers against thermal decomposition. Finally, the mass loss above $550^{\circ} \mathrm{C}$ was attributed to the dehydroxylation of the clay mineral. Even at low spermine loadings, the dehydroxylation feature of $\mathrm{Na}-\mathrm{SWy}-2$ was shifted to lower temperature (Fig. 3). There was a very good linear relationship $\left(R^{2}=0.988\right)$ between the amounts of spermine in the samples, as determined by the second mass loss of the thermograms, and the amounts calculated by assuming that all spermine added was incorporated into the SSFs (Fig. 3). Nevertheless, the amounts of organic cations in the samples with higher amounts of spermine might have been overestimated due to the 
overlapping between the mass loss of spermine and the dehydroxylation of montmorillonite (Fig. 3).

\subsubsection{FTIR study}

The FTIR spectra of SSFs of Na-SWy-2 reacted with different amounts of spermine were normalized to the band of the stretching mode of structural $\mathrm{OH}$ groups of smectite, $v(\mathrm{OH})$, at $3630 \mathrm{~cm}^{-1}$, which was used as an internal standard (Fig. 4). The position of this band was slightly shifted to lower wavenumbers upon saturation of Na-SWy-2 with spermine (Fig. 4A), presumably due to the interaction between the organic cations and the montmorillonite layers. This explained the impact of spermine on the dehydroxylation temperature of the clay mineral as observed in the TGA study. The broad band appearing in the spectra near $3400 \mathrm{~cm}^{-1}$ (Fig. 4A) corresponded to the $\mathrm{O}-\mathrm{H}$ stretching vibration of water. The intensity of this band decreased with the amount of spermine in the samples, reflecting the lower hydration of the spermine-exchanged samples.

The bands appearing in the spectra at $3125-2770 \mathrm{~cm}^{-1}$ (Fig. 4A) were attributed to the N-H stretching vibrations of the protonated $-\mathrm{NH}_{3}{ }^{+}$and $-\mathrm{NH}_{2}{ }^{+}$- groups and to the $\mathrm{C}-\mathrm{H}$ stretching vibrations of the $-\mathrm{CH}_{2}$ - groups of spermine whereas the group of bands between 1595 and $1455 \mathrm{~cm}^{-1}$ (Fig. 4B) were assigned to the N-H and C-H deformation modes of the organic polycation (Celis et al., 2007). Broadening and shifting of the bands of C-H and $-\mathrm{NH}_{3}{ }^{+}$and $\mathrm{NH}_{2}{ }^{+}$of montmorillonite-spermine compared to pure spermine tetrahydrochloride (Fig. 4) indicated involvement of such groups in the interaction between the organic cations and the montmorillonite. In particular, the position of the band at $1525 \mathrm{~cm}^{-1}$ in Fig. 4B was consistent with previously reported values for the $\mathrm{N}-\mathrm{H}$ deformation vibration of protonated amine groups interacting with the layer charges (Darder et al., 2003; Monvisade and Siriphannon, 2009). Interestingly, integration of the bands between 1575 and $1375 \mathrm{~cm}^{-1}$ resulted in a linear 
relationship with the amount of spermine added up to $0.9 \times \mathrm{CEC}$ (Fig. 5). This supported the high affinity of spermine for SWy-2 montmorillonite up to an amount close to the CEC of the clay mineral.

To complement the FTIR results obtained with SSFs, an in situ ATR-FTIR experiment was carried out to further characterize the montmorillonite-spermine samples (Fig. 6). In the in situ ATR-FTIR spectra of water, Na-SWy-2 in water, and Na-SWy-2 after reaction with spermine at the highest concentration (Fig. 6A, 6B, and 6C), the most prominent bands were the $\mathrm{OH}$ stretching $\left(\sim 3500 \mathrm{~cm}^{-1}\right)$ and bending $\left(1639 \mathrm{~cm}^{-1}\right)$ bands of water. In addition, the $v(\mathrm{Si}-$ O) band of Na-SWy-2 $\left(1040 \mathrm{~cm}^{-1}\right)$ was also visible in the spectra 6B and 6C. Subtraction of the water signal was used to evaluate modifications in the absorption bands of Na-SWy-2 after adsorption of spermine (Fig. 6D and 6E). In the extended view of spectrum $6 \mathrm{E}$, the N-H and C-H deformation band of spermine was identified at $1479 \mathrm{~cm}^{-1}$ (Fig. 6F), whereas this band appeared at $1473 \mathrm{~cm}^{-1}$ in the spectrum of spermine at $30 \mathrm{mM}$ in the ATR-FTIR cell (Fig. 6G). Therefore, the position of the N-H and C-H deformation band of spermine at $1479 \mathrm{~cm}^{-1}$ in Fig. $6 \mathrm{~F}$ showed a shift as a result of the interaction of spermine with the clay mineral. The area of this band was plotted as a function of the amount of spermine added to Na-SWy-2 (Fig. 5). The curve reached a plateau close to the CEC, which was in agreement with SSF data and previous studies of Celis et al. (2007). Most likely, the limited amount of intercalated spermine was due to the saturation of the CEC of SWy-2. Consequently, the in situ ATRFTIR technique gave not only useful qualitative information on organic modification of montmorillonite but also quantitative information in agreement with FT-IR analysis of SSFs (Fig. 5).

\subsubsection{Structure modeling}


Molecular dynamics modeling indicated that the most favorable arrangement of spermine cations in the interlayer space of SWy-2 would be an almost parallel orientation of spermine cations with $-\mathrm{NH}_{3}{ }^{+}$and $-\mathrm{NH}_{2}{ }^{+}$- groups being keyed into the ditrigonal cavities of the layers with formation of hydrogen bonds to the surface oxygen atoms (Fig. 7). The ditrigonal cavities have a diameter which is close to the size of the $\mathrm{NH}_{4}{ }^{+}$ion (Johnston and Tombàcz, 2002), and this may have favored the interaction of spermine with SWy-2. The proposed conformation would result in a basal spacing of about $1.15 \mathrm{~nm}$ for the dehydrated system. The observed spacing of $1.29 \mathrm{~nm}$ for air-dried spermine-montmorillonites (Fig. 2) was reasonable assuming the presence of some water molecules in the interlayer space. Serratosa et al. (1984) reported a similar $\mathrm{d}_{001}$-value of $1.32 \mathrm{~nm}$ for medium-charged vermiculite intercalated with butylammonium ions, with the $\mathrm{NH}_{3}{ }^{+}$end-groups being keyed into the ditrigonal cavities of the clay mineral. Celis et al. (2007) observed that the basal spacing of spermine-saturated SWy-2 decreased to $1.24 \mathrm{~nm}$ after heating $200^{\circ} \mathrm{C}$, thus approaching to the value predicted for the completely dehydrated system.

Considering the surface charge density of SWy-2 as $1.07 \mathrm{mmol}$ charges per $\mathrm{m}^{2}$ (Table 1), the distance between two adjacent charges in spermine (0.5-0.6 nm, Fig. 1) would be shorter than the average distance between two permanent adjacent charges of the SWy-2 layer $(\sim 1.4$ $\mathrm{nm})$. However, because montmorillonite layers are stacked on top of each other, the effective surface charge density would be increased by a factor of two and the average separation between negatively charged sites would be further reduced to about $0.7 \mathrm{~nm}$. Thus, a single spermine cation could compensate adjacent charges located on the two opposite montmorillonite layers. In addition, octahedral substitution (e.g. $\mathrm{Mg}^{2+}$ replacing $\mathrm{Al}^{3+}$ ) in smectites results in a charge deficit which is delocalized up to over 8 surface oxygen atoms (0.7 $\mathrm{nm})$ on each side of the fundamental particles (Johnston, 2010). This further made the charge distribution in SWy-2 reasonably compatible with the distance between charges in the 
spermine polycation. Thus, the charge separation in spermine may have contributed to strengthen the clay mineral-organic interaction and to reduce the basal spacing as compared to previously reported values for alkylammonium-exchanged montmorillonites (Jordan, 1949; Lagaly, 1981; Serratosa et al., 1984).

\subsection{Montmorillonite-spermine-fluometuron}

Fluometuron adsorption isotherms on Na-SWy-2 reacted with spermine at 0.6 and $1.2 \times$ CEC of the clay mineral were obtained during the preparation of montmorillonite-spermineFluometuron SSFs (Fig. 8). The isotherms showed the high affinity of fluometuron for spermine-exchanged montmorillonites and indicated that higher amounts of spermine increased the adsorption of fluometuron. Previous studies showed that unexchanged SWy-2 montmorillonite had little affinity for fluometuron (Gámiz et al., 2010). The adsorption isotherm of fluometuron on Na-SWy-2 reacted with spermine at $1.2 \times \mathrm{CEC}$ (Fig. 8) was very similar to that reported by Gámiz et al. (2010) for fluometuron adsorption on a sperminesaturated SWy-2 sample, despite the adsorption data were obtained under slightly different experimental conditions.

Montmorillonite-spermine-fluometuron SSFs were characterized by XRD and TGA. Both the basal spacing and the second mass loss of the montmorillonite-spermine SSFs remained unchanged after fluometuron adsorption. This could be due to the relatively small fluometuron content of the SSFs, which was $<3$ g herbicide $\mathrm{kg}^{-1}$ (i.e., $13 \mathrm{mmol} \mathrm{kg}^{-1}$ ) in all cases (Fig. 8). In the diffuse reflectance spectrum of fluometuron (Fig. 9H), the main absorption bands appeared at $1656 \mathrm{~cm}^{-1}$ for the stretching vibration of the carbonyl group, at 1540 and $1124 \mathrm{~cm}^{-}$

${ }^{1}$ for benzene ring stretching bands, and at $1336 \mathrm{~cm}^{-1}$ for the $-\mathrm{CF}_{3}$ stretching vibration (Quintás et al., 2003). The most significant feature of the spectra of SSFs was the shifting of the band corresponding to the $-\mathrm{CF}_{3}$ group of adsorbed fluometuron at $1333 \mathrm{~cm}^{-1}$, towards 
lower wavenumbers compared to the pure compound. The intensity of this band at $1333 \mathrm{~cm}^{-1}$ increased after each herbicide addition during the in situ ATR-FTIR experiment. The area of the band at $1333 \mathrm{~cm}^{-1}$ as a function of the amount of fluometuron added reached a plateau (Fig. 10), which would correspond to the maximum herbicide uptake by the spermine saturated Na-SWy-2, determined by HPLC measurements as $\sim 12 \mathrm{~g} \mathrm{~kg}^{-1}$ (i.e., $52 \mathrm{mmol} \mathrm{kg}^{-1}$ ).

\section{Conclusions}

Spermine is readily intercalated into Na-saturated Wyoming montmorillonite up to an amount close to the CEC of the clay mineral, with basal spacings between 1.45 to $1.29 \mathrm{~nm}$ as the spermine content increased. Spermine-intercalated SWy-2 displayed greater resistance to expansion by hydration than the original Na-saturated montmorillonite. TGA data showed that the intercalation of spermine in SWy-2 increased the thermal stability of the polycation and reduced the dehydroxylation temperature of the clay mineral. FTIR spectroscopy data indicated involvement of aliphatic and amino groups of spermine in the interaction with the montmorillonite surface. These results were consistent with the arrangement of the spermine polycations in monolayers parallel to the silicate layers. The $\mathrm{NH}_{3}{ }^{+}$and $\mathrm{NH}_{2}{ }^{+}$groups of the polycations are keying into the ditrigonal cavities of the layers as a result of strong interaction between these groups and the SWy-2 surface oxygens. In accordance with previous studies, adsorption and FT-IR measurements indicated a high affinity of spermine-montmorillonite to the phenylurea herbicide fluometuron.

\section{Acknowledgements}

This work has been financed by Junta de Andalucía (Project P07-AGR-03077), the Spanish Ministry of Science and Innovation (Project AGL2008-04031-C02-01), and the European Union (Project PIRSES-GA-2008-230796 and FEDER-FSE funds). The authors 
thank Brian J. Teppen and Cun Liu for their help with the molecular dynamics modeling section. Beatriz Gámiz also thanks Junta de Andalucía for her FPI fellowship.

\section{References}

Baskaran, S., Kennedy, I.R., 1999. Sorption and desorption kinetics of diuron, fluometuron, prometryn and pyrithiobac sodium in soils. J. Environ. Sci. Health B 34, 943-963.

Bergaya, F., Lagaly, G., 2006. General introduction: clays, clay minerals, and clay science, in: Bergaya, F., Theng, B.K.G., Lagaly, G. (Eds.), Handbook of Clay Science. Elsevier, Amsterdam, pp. 1-18.

Boyd, S.A., Johnston, C.T., Laird, D.A., Teppen, B.J., Li, H., 2011. Comprehensive study of organic contaminant adsorption by clays: methodologies, mechanisms, and environmental implications, in: Xing, B., Senesi, N., Huang, P.M. (Eds.), Biophysico-Chemical Processes of Anthropogenic Organic Compounds in Environmental Systems. John Wiley \& Sons, Inc., pp. 51-71.

Boyd, S.A., Shaobai, S., Lee, J.F., Mortland, M.M., 1988. Pentachlorophenol sorption by organo-clays. Clays Clay Miner. 36, 125-130.

Celis, R., Trigo, C., Facenda, G., Hermosín, M.C., Cornejo, J., 2007. Selective modification of clay minerals for the adsorption of herbicides widely used in olive groves. J. Agric. Food Chem. 55, 6650-6658.

Chipera, S.J.., Bish, D.L., 2001. Baseline studies of The Clay Minerals Society Source Clays: powder X-ray diffraction analyses. Clays Clay Miner. 49, 398-409.

Cornejo, J., Celis, R., Pavlovic, I., Ulibarri, M.A., 2008. Interactions of pesticides with clays and layered double hydroxides: a review. Clay Miner. 43, 155-175. 
Cruz-Guzmán, M., Celis, R., Hermosín, M.C., Cornejo, J., 2004. Adsorption of the herbicide simazine by montmorillonite modified with natural organic cations. Environ. Sci. Technol. 38, 180-186.

Cruz-Guzmán, M., Celis, R., Hermosín, M.C., Koskinen, W.C., Cornejo, J., 2005. Adsorption of pesticides from water by functionalized organobentonites. J. Agric. Food Chem. 53, $7502-7511$.

Darder, M., Colilla, M., Ruiz-Hitzky, E., 2003. Biopolymer-clay nanocomposites based on chitosan intercalated in montmorillonite. Chem. Mater. 15, 3774-3780.

Frassineti, C., Ghelli, S., Gans, P., Sabatini, A., Moruzzi, M.S., Vacca, A., 1995. Nuclear magnetic resonance as a tool for determining protonation constants of natural polyprotic bases in solution. Anal. Biochem. 231:374-382.

Gámiz, B., Celis, R., Hermosín, M.C., Cornejo, J., 2010. Organoclays as soil amendments to increase the efficacy and reduce the environmental impact of the herbicide fluometuron in agricultural soils. J. Agric. Food Chem. 58, 13, 7893-7901.

Gaston, L.A., Boquet, D.J., Bosch, M.A., 2003. Fluometuron sorption and degradation in cores of silt loam soil from different tillage and cover crop systems. Soil Sci. Soc. Am. J. $67,747-755$

Gonen, Y., Rytwo, G., 2006. Using the dual-mode model to describe adsorption of organic pollutants onto an organoclay. J. Colloid Interface Sci. 299, 95-101.

Groisman, L., Rav-Acha, C., Gerstl, Z., Mingelgrin, U., 2004. Sorption of organic compounds of varying hydrophobicities from water and industrial wastewater by long- and short-chain organoclays. Appl. Clay Sci. 24, 159-166.

Halladja, S., Amine-Khodja, A., ter Halle, A., Boulkamh, A., Richard, C., 2007. Photolysis of fluometuron in the presence of natural water constituents. Chemosphere 69, 1647-1654. 
Hermosín, M.C., Cornejo, J., 1992. Removing 2,4-D from water by organo-clays. Chemosphere 24, 1493-1503.

Jaynes, W.F., Vance, G.F., 1996. BTEX sorption by organo-clays: cosorptive enhancement and equivalence of interlayer complexes. Soil Sci. Soc. Am. J. 60, 1742-1749.

Johnston, C.T., 2010. Probing the nanoscale architecture of clay minerals. Clay Miner. 45, 245-279.

Johnston, C.T., Tombàcz, E., 2002. Surface chemistry of soil minerals, in: Dixon, J.B., Schulze, D.G. (Eds.), Soil Mineralogy with Environmental Applications. SSSA Book Series 7, Madison, WI., pp. 37-67.

Jordan, J.W., 1949. Organophilic bentonites. I. Swelling in organic liquids. J. Phys. Chem. 53, 294-306.

Lagaly, G., 1981. Characterization of clays by organic compounds. Clay Miner. 16, 1-21.

Li, H., Teppen, B.J., Johnston, C.T., Boyd, S.A., 2004. Thermodynamics of nitroaromatic compound adsorption from water by smectite clay. Environ. Sci. Technol. 38, 5433-5442.

Locke, M.A., Weaver, M.A., Zablotowicz, R.M., Steinriede, R.W., Bryson, C.T., Cullum, R.F., 2011. Constructed wetlands as a component of the agricultural landscape: Mitigation of herbicides in simulated runoff from upland drainage areas. Chemosphere 83, 15321538.

Locke, M.A., Zablotowicz, R.M., Steinriede, R.W., Kingery, W.L., 2007. Degradation and sorption of fluometuron and metabolites in conservation tillage soils. J. Agric. Food Chem. 55, 844-851.

Monvisade, P., Siriphannon, P., 2009. Chitosan intercalated montmorillonite: preparation, characterization and cationic dye adsorption. Appl. Clay Sci. 42, 427-431.

Mortland, M.M., 1970. Clay-organic interactions. Adv. Agron. 23, 75-117. 
Mortland, M.M., Shaobai, S., Boyd, S.A., 1986. Clay-organic complexes as adsorbents for phenol and chlorophenols. Clays Clay Miner. 34, 581-585.

Mueller, T.C., Moorman, T.B., Snipes, C.E., 1992. Effect of concentration, sorption, and microbial biomass on degradation of the herbicide fluometuron in surface and subsurface soils. J. Agric. Food Chem. 40, 2517-2522.

Nam, H.-J., Ebina, T., Mizukami, F., 2009. Formability and properties of self-standing clay film by montmorillonite with different interlayer cations. Colloid Surface A 346, 158-163.

Nir, S., El-Nahhal, Y., Undabeytia, T., Rytwo, G., Polubesova, T., Mishael, Y., Rabinovitz, U., Rubin, B., 2006. Clays and pesticides, in: Bergaya, F., Theng, B.K.G., Lagaly, G. (Eds.), Handbook of Clay Science. Elsevier, Amsterdam, pp. 677-691.

Nye, J.V., Guerin, W.F., Boyd, S.A., 1994. Heterotrophic activity of microorganisms in soils treated with quaternary ammonium compounds. Environ. Sci. Technol. 28, 944-951.

Quintás, G., Morales-Noé, A., Parrilla, C., Garrigués, S., de la Guardia, M., 2003. Fourier transform infrared determination of Fluometuron in pesticide formulations. Vib. Spectrosc. 31, 63-69.

Rana, K., Boyd, S.A., Teppen, B.J., Li, H., Liu, C., Johnston, C.T., 2009. Probing the microscopic hydrophobicity of smectite surfaces. A vibrational spectroscopic study of dibenzo-p-dioxin sorption to smectite. Phys. Chem. Chem. Phys. 11, 2976-2985.

Sarkar, B., Megharaj, M., Xi, Y., Krishnamurti, G.S.R., Naidu, R., 2010. Sorption of quaternary ammonium compounds in soils: Implications to the soil microbial activities. J. Hazard. Mater. 184, 448-456.

Serratosa, J.M., Rausell-Colom, J.A., Sanz, J., 1984. Charge density and its distribution in phyllosilicates: Effect on the arrangement and reactivity of adsorbed species. J. Molecular Catal. 27, 225-234. 
Sheng, G., Johnston, C.T., Teppen, B.J., Boyd, S.A., 2002. Adsorption of dinitrophenol herbicides from water by montmorillonite. Clays Clay Miner. 50, 25-34.

Wagner, S.C., Zablotowicz, R.M., 1997. Effect of organic amendments on the bioremediation of cyanazine and fluometuron in soil. J. Environ. Sci. Health B 32, 37-54.

Weaver, M.A., Zablotowicz, R.M., Locke, M.A., 2004. Laboratory assessment of atrazine and fluometuron degradation in soils from a constructed wetland. Chemosphere 57, 853-862.

Worthing, C.R., Hance, R.J., 1991. The Pesticide Manual. British Crop Protection Council, Surrey, U.K.

Xi, Y., Martens, W., He, H., Frost, R.L., 2005. Thermogravimetric analysis of organoclays intercalated with the surfactant octadecyltrimethylammonium bromide. J. Therm. Anal. Calorim. 81, 91-97.

Yariv, S., 2004. The role of charcoal on DTA curves of organo-clay complexes: an overview. Appl. Clay Sci. 24, 225-236.

Zablotowicz, R.M., Locke, M.A., Gaston, L.A., Bryson, C.T., 2000. Interactions of tillage and soil depth on fluometuron degradation in a Dundee silt loam soil. Soil Till. Res. 57, 6168.

Zhao J., Wilkins, R.M., 2003. Controlled release of the herbicide, fluometuron, from matrix granules based on fractioned organosolv lignins. J. Agric. Food Chem. 51, 4023-4028. 
Fig. 1. Structure of fluometuron and spermine.

Fig. 2. X-ray diffraction patterns of self-supporting films (SSFs) of Na-SWy-2 reacted with amounts of spermine ranging between 0 and $1.2 \times \mathrm{CEC}$ of the clay mineral: A) air-dried SSFs, B) water-saturated SSFs. amount of spermine in the samples and the amount added (right). 
Fig. 6. ATR-FTIR spectra of (A) $\mathrm{H}_{2} \mathrm{O}$, (B) Na-SWy-2 in water, (C) spermine-saturated NaSWy-2, (D) Na-SWy-2 with spectrum of $\mathrm{H}_{2} \mathrm{O}$ subtracted, (E) spermine-saturated Na-SWy-2 with spectrum of $\mathrm{H}_{2} \mathrm{O}$ subtracted, (F) extended view of spectrum (E) showing the diagnostic vibration band of spermine adsorbed on SWy-2, (G) aqueous solution of $30 \mathrm{mM}$ spermine.

Fig. 7. Schematic representation of the possible arrangement of spermine polycations in the interlayer space of SWy-2 at dehydrated conditions. All distances are given in nanometers.

Fig. 8. Fluometuron adsorption isotherms on Na-SWy-2 reacted with an amount of spermine corresponding to 0.6 and $1.2 \times \mathrm{CEC}$ of the clay mineral. Error bars correspond to the standard errors of duplicate measurements.

Fig. 9. FTIR spectra of (A) SSF of Na-SWy-2, (B) SSF of Na-SWy-2 reacted with spermine at $1.2 \times \mathrm{CEC},(\mathrm{C}) \mathrm{SSF}$ of Na-SWy-2 reacted with spermine at $1.2 \times \mathrm{CEC}$ and then with a $5 \mathrm{mg}$

$\mathrm{L}^{-1}$ fluometuron solution, (D) extended view of spectrum (C), (E) in situ ATR-FTIR spectrum of Na-SWy-2 saturated with spermine with spectrum of $\mathrm{H}_{2} \mathrm{O}$ subtracted, (F) in situ ATR-FTIR spectrum of Na-SWy-2 saturated with spermine and fluometuron with spectrum of $\mathrm{H}_{2} \mathrm{O}$ subtracted, (G) extended view of spectrum (F) showing the diagnostic vibration band of fluometuron adsorbed on montmorillonite-spermine, $(\mathrm{H})$ fluometuron spectrum in diffuse reflectance.

Fig. 10. Area of the fluometuron $-\mathrm{CF}_{3}$ band after successive herbicide additions to sperminesaturated SWy-2 during the in situ ATR-FTIR experiment. 
Click here to download Table: Table 1.doc

\section{Table 1}

Properties of SWy-2 montmorillonite. ${ }^{a}$

\begin{tabular}{cccccc}
\hline \multicolumn{1}{c}{ Ideal Formula } & $\begin{array}{c}\text { Octahedral } \\
\text { sheet type }\end{array}$ & $\begin{array}{c}\text { Tetrahedral } \\
\text { charge } \\
\text { content } \\
(\%)\end{array}$ & $\begin{array}{c}\mathrm{CEC} \\
\left(\mathrm{cmol}_{\mathrm{c}} \mathrm{kg}^{-1}\right)\end{array}$ & $\begin{array}{c}\text { Specific } \\
\text { surface } \\
\text { area } \\
\left(\mathrm{m}^{2} \mathrm{~g}^{-1}\right)\end{array}$ & $\begin{array}{c}\text { Surface } \\
\text { charge } \\
\text { density } \\
\left(\mathrm{mmol} \mathrm{m}^{-2}\right)\end{array}$ \\
\hline $\mathrm{M}_{0.33}^{+}\left(\mathrm{Si}_{4}\right)^{\mathrm{IV}}\left(\mathrm{Al}_{1.67} \mathrm{Mg}_{0.33}\right)^{\mathrm{VI} \mathrm{O}_{10}(\mathrm{OH})_{2}}$ & Dioctahedral & 3.6 & 82 & 750 & 1.07 \\
\hline${ }^{\mathrm{a}}$ Data from Rana et al. (2009). & & & &
\end{tabular}

${ }^{\mathrm{a}}$ Data from Rana et al. (2009). 


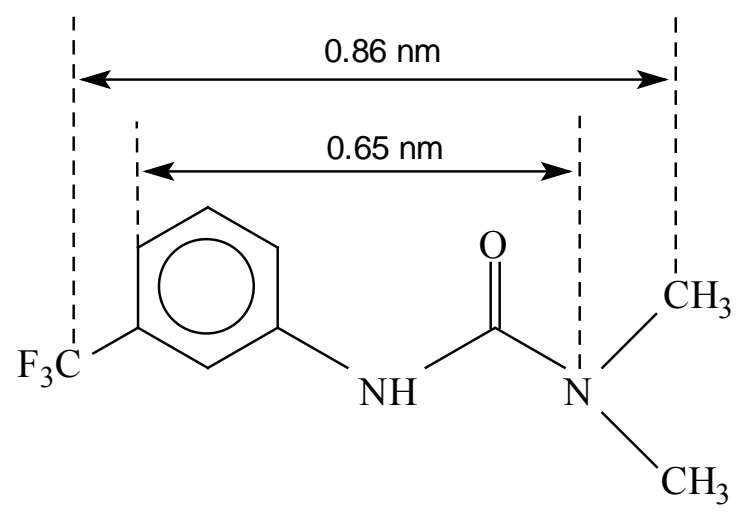

Fluometuron

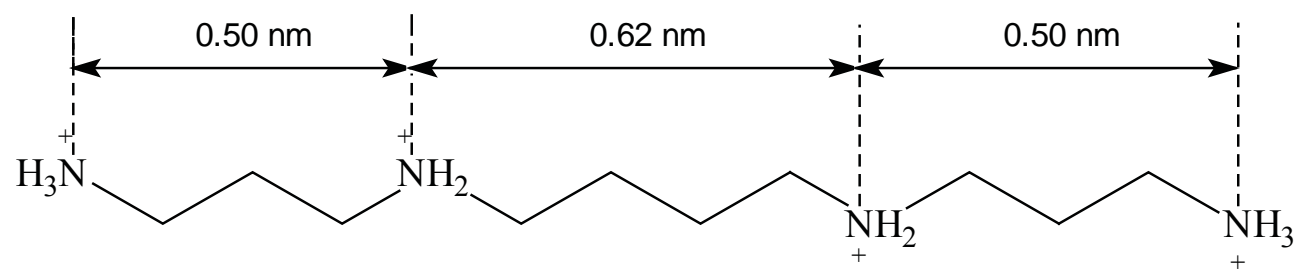

Spermine

Fig. 1. Structure of fluometuron and spermine. 

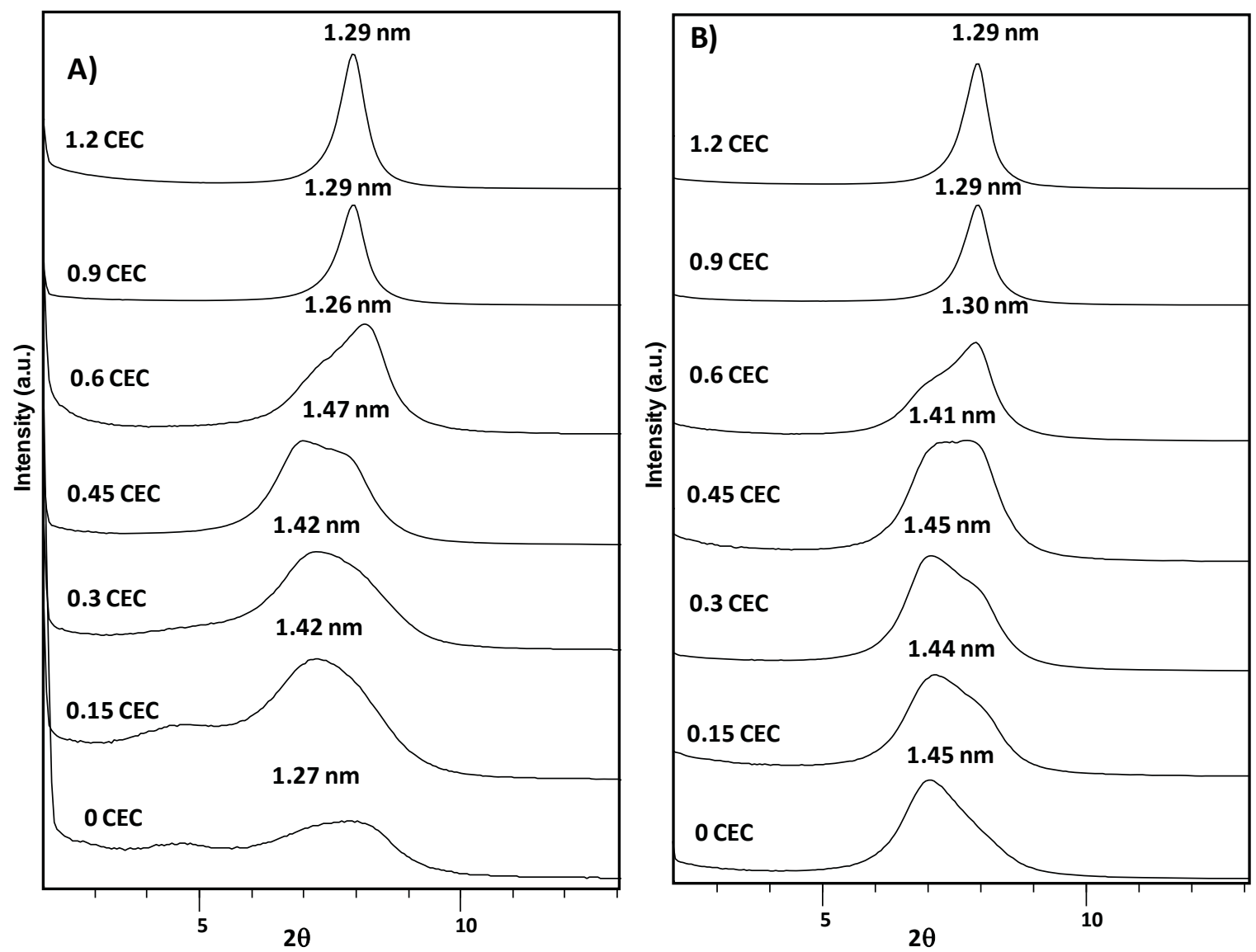

Fig. 2. X-ray diffraction patterns of self-supporting films (SSFs) of Na-SWy-2 reacted with amounts of spermine ranging between 0 and $1.2 \times$ CEC of the clay mineral: A) air-dried SSFs, B) water-saturated SSFs. 

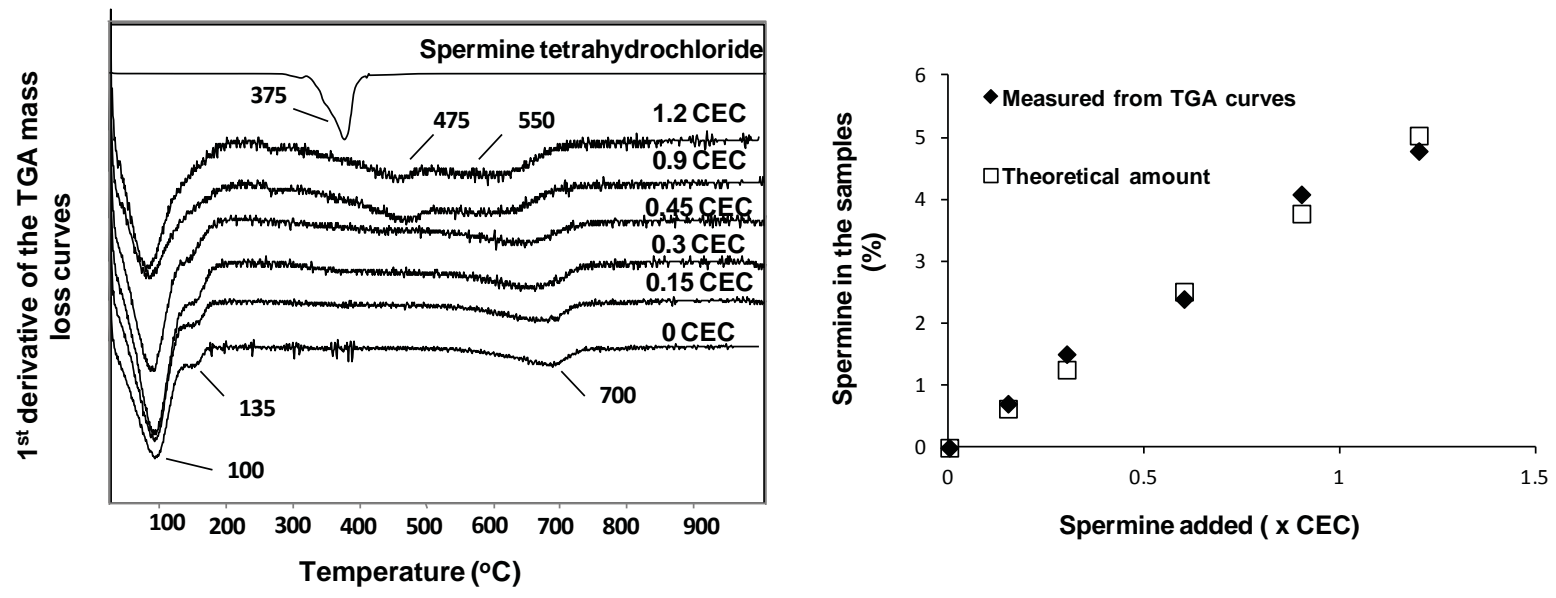

Fig. 3. First derivative of the TGA mass loss of spermine tetrahydrochloride and $\mathrm{Na}-\mathrm{SWy}-2$ reacted with different amounts of spermine (left) and the linear relationship between the amount of spermine in the samples and the amount added (right). 

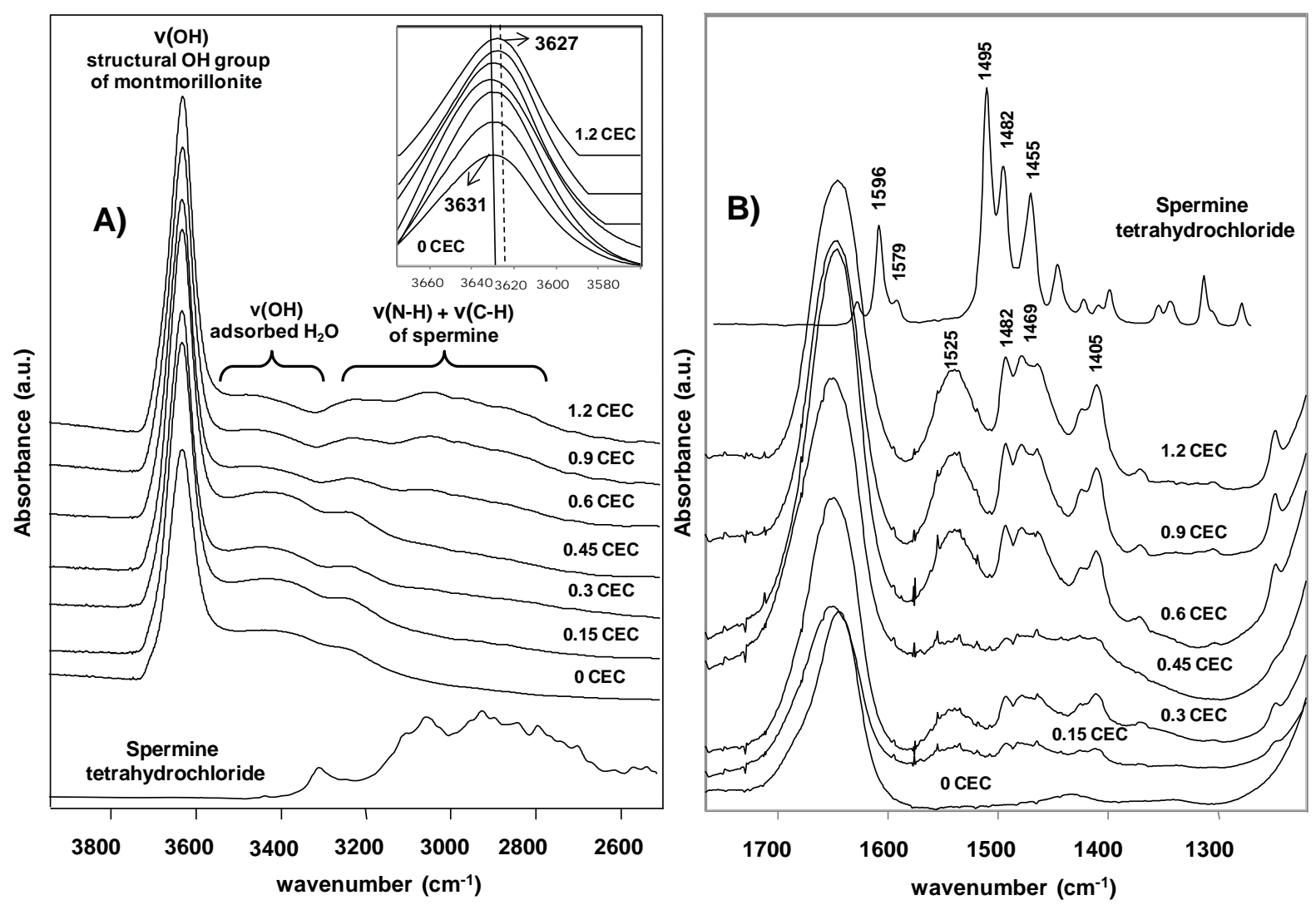

Fig. 4. Selected regions of the FT-IR spectra of spermine tetrahydrochloride and sperminereacted Na-SWy-2 SSFs: A) region showing the $\mathrm{N}-\mathrm{H}$ and $\mathrm{C}-\mathrm{H}$ stretching modes of spermine, the stretching mode of adsorbed water and the stretching mode of structural $\mathrm{OH}$ groups of montmorillonite, B) region showing the $\mathrm{N}-\mathrm{H}$ and $\mathrm{C}-\mathrm{H}$ deformation modes of spermine. Enlarged: region of structural $\mathrm{OH}$ groups of montmorillonite. 


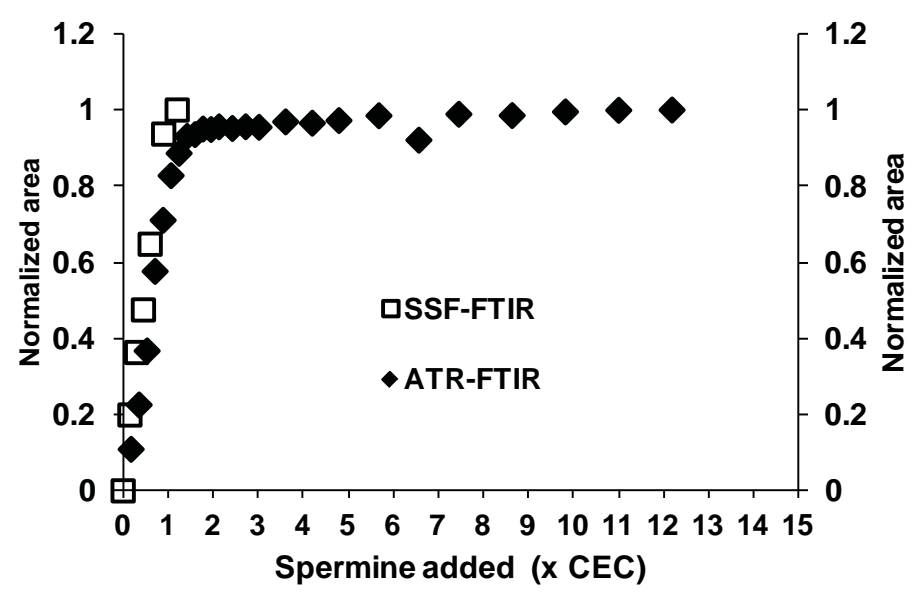

Fig. 5. Relationship between the area of the bands corresponding to spermine $\mathrm{N}-\mathrm{H}$ and $\mathrm{C}-\mathrm{H}$ deformation modes and the amount of spermine added to Na-SWy-2. Comparison of the SSFs and ATR-FTIR data. All areas were normalized to that obtained after adding spermine at $1.2 \times$ CEC of SWy-2. 


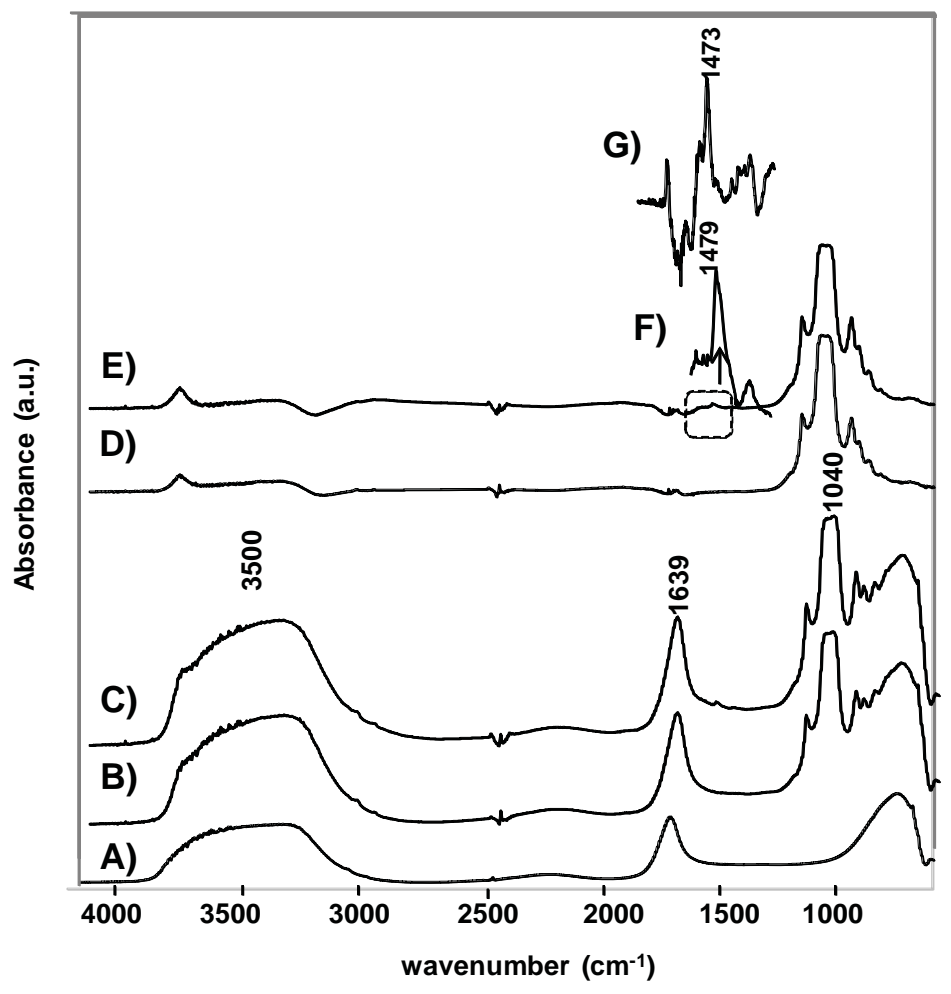

Fig. 6. ATR-FTIR spectra of (A) $\mathrm{H}_{2} \mathrm{O}$, (B) Na-SWy-2 in water, (C) spermine-saturated NaSWy-2, (D) Na-SWy-2 with spectrum of $\mathrm{H}_{2} \mathrm{O}$ subtracted, (E) spermine-saturated Na-SWywith spectrum of $\mathrm{H}_{2} \mathrm{O}$ subtracted, $(\mathrm{F})$ extended view of spectrum (E) showing the diagnostic vibration band of spermine adsorbed on SWy-2, (G) aqueous solution of $30 \mathrm{mM}$ spermine. 

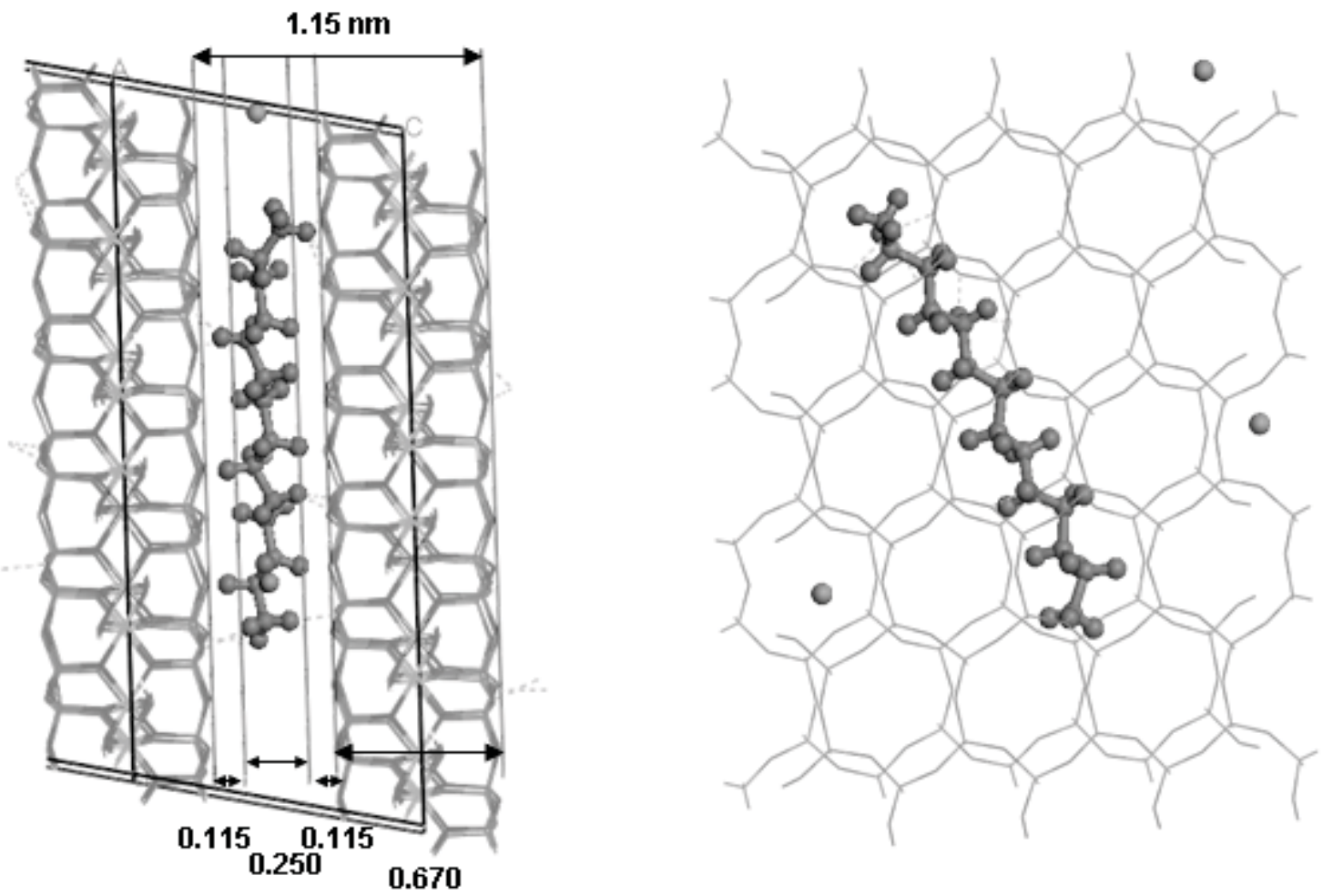

Fig. 7. Schematic representation of the possible arrangement of spermine polycations in the interlayer space of SWy-2 at dehydrated conditions. All distances are given in nanometers. 


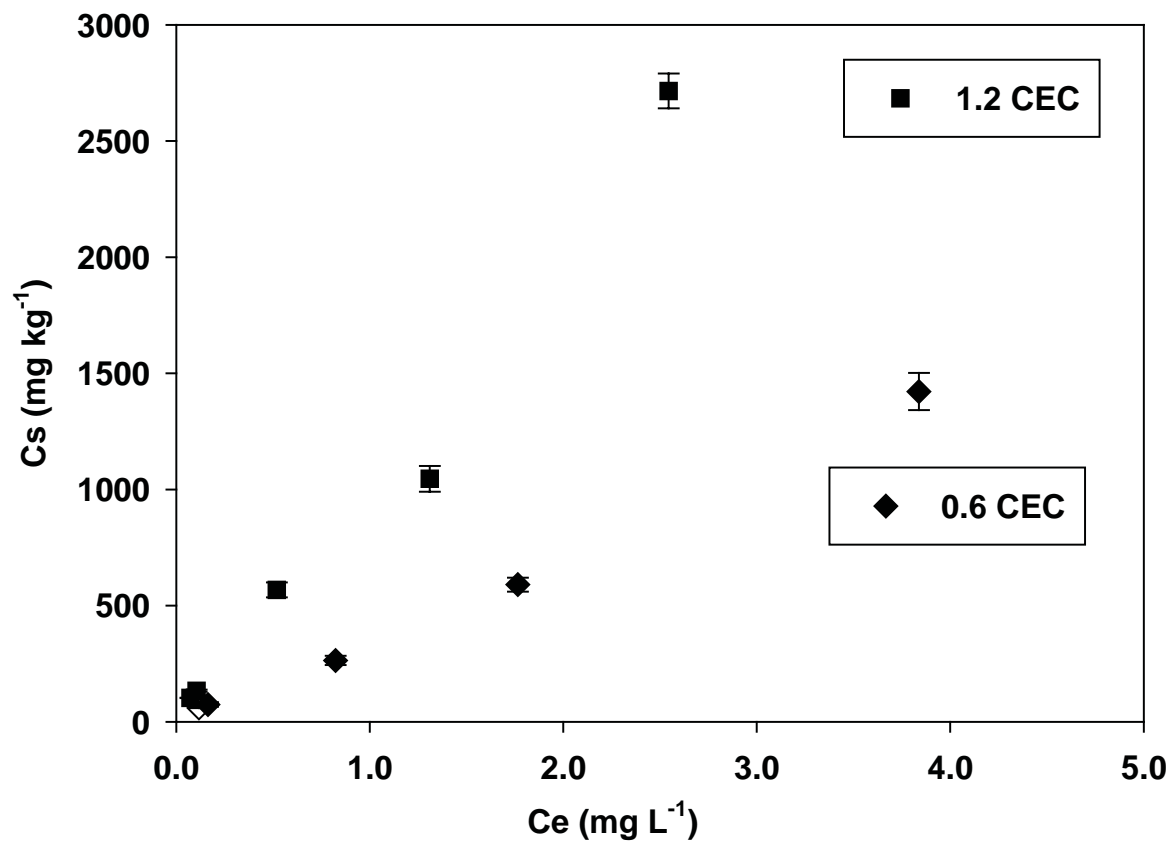

Fig. 8. Fluometuron adsorption isotherms on $\mathrm{Na}-\mathrm{SWy}-2$ reacted with an amount of spermine corresponding to 0.6 and $1.2 \times \mathrm{CEC}$ of the clay mineral. Error bars correspond to the standard errors of duplicate measurements. 


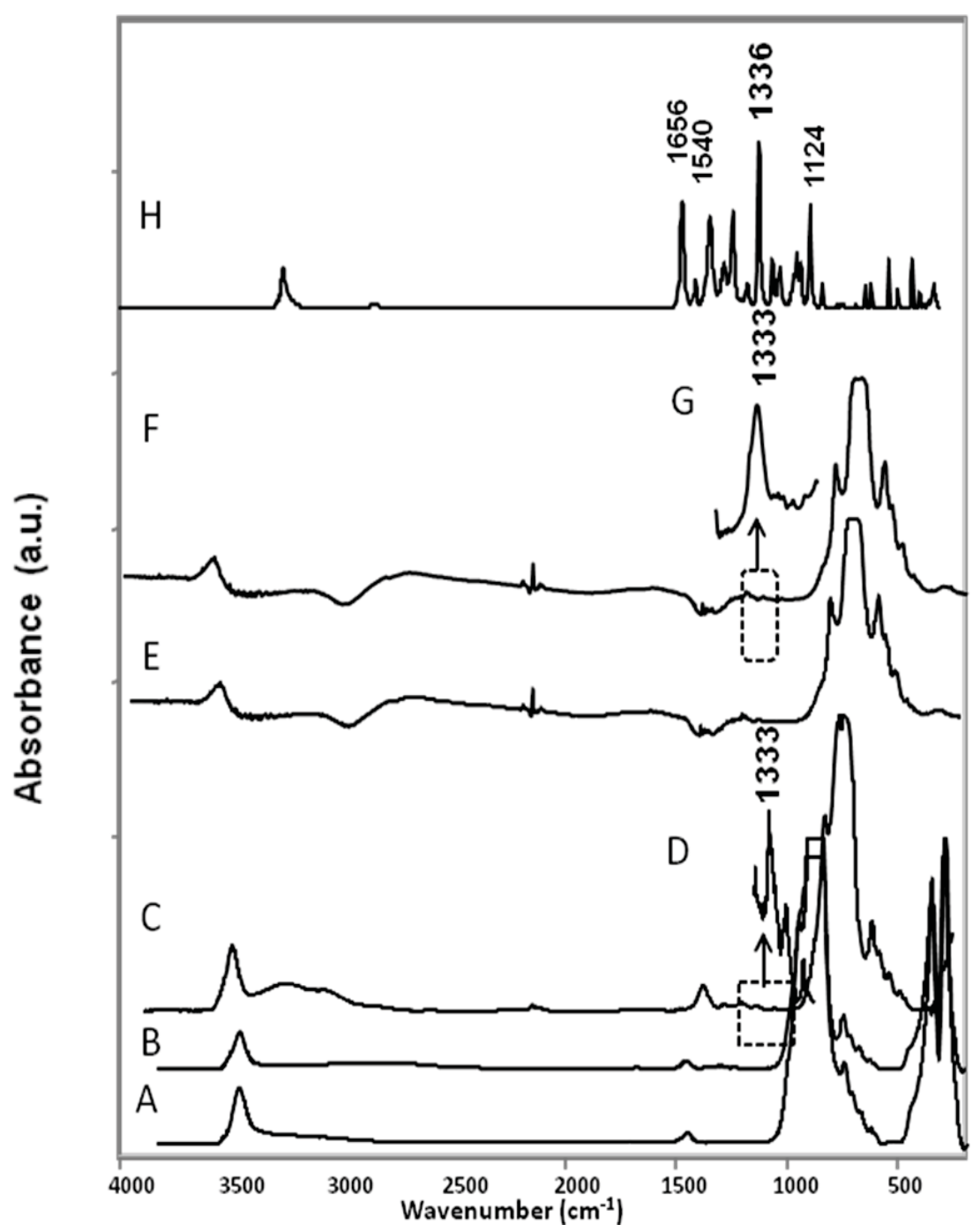

Fig. 9. FTIR spectra of (A) SSF of Na-SWy-2, (B) SSF of Na-SWy-2 reacted with spermine at $1.2 \times \mathrm{CEC},(\mathrm{C}) \mathrm{SSF}$ of Na-SWy-2 reacted with spermine at $1.2 \times \mathrm{CEC}$ and then with a $5 \mathrm{mg}$ $\mathrm{L}^{-1}$ fluometuron solution, (D) extended view of spectrum (C), (E) in situ ATR-FTIR spectrum of Na-SWy-2 saturated with spermine with spectrum of $\mathrm{H}_{2} \mathrm{O}$ subtracted, (F) in situ ATR-FTIR spectrum of Na-SWy-2 saturated with spermine and fluometuron with spectrum of $\mathrm{H}_{2} \mathrm{O}$ subtracted, (G) extended view of spectrum (F) showing the diagnostic vibration band of fluometuron adsorbed on montmorillonite-spermine, $(\mathrm{H})$ fluometuron spectrum in diffuse reflectance. 


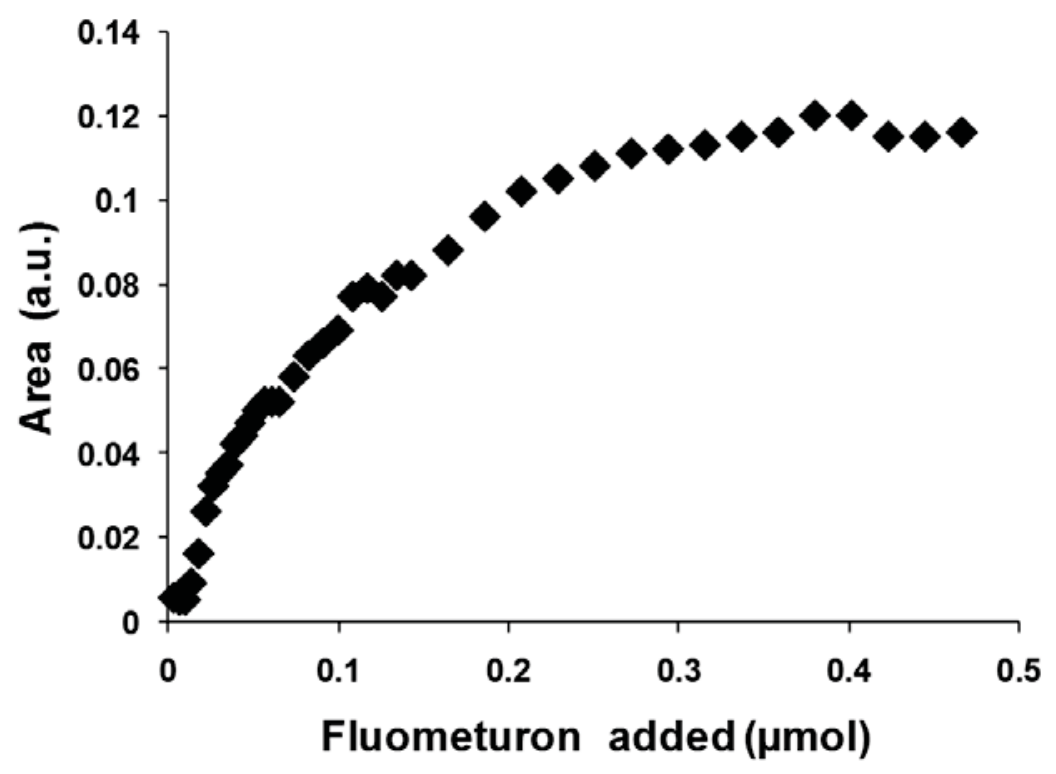

Fig. 10. Area of the fluometuron $-\mathrm{CF}_{3}$ band after successive herbicide additions to sperminesaturated SWy-2 during the in situ ATR-FTIR experiment. 